\title{
$\mathrm{MFC} / \mathrm{MF}$ スクリーンによる省エネ実施例* \\ ースクリーニングシステムの再構築一
}

石川島産業機械株式会社 岩 重 尚之

\section{Field Experience and Power Saving by the MFC/MF Screen}

\section{Naoyuki Iwashige}

Ishikawajima Industrial Machinery Co., Ltd.

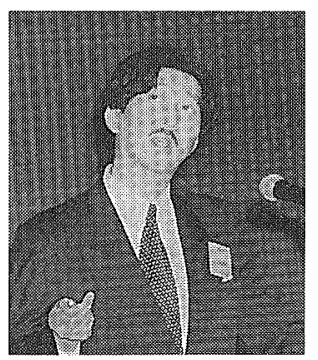

The MFC/MF Screen, developed by Ishikawajima Industrial Machinery Co., was introduced in the annual meeting of JAPAN TAPPI last year.

The MFC/MF Screen will enormously reduce the reject rate and extensively simplify the conventional screen system, while keeping the screening efficiency of the accepted pulp. In consequence, the MFC/MF Screen will reduce both initial and running cost by approximately 50 percent compared with the conventional screen system.

Herewith, some of the field data of the MFC/MF Screen are presented for reference to understand how the performance are superior.

Keywords: MF Screen, MFC screen, Screen system, Secondary fiber, Reject rate

\section{1.はじめに}

地球的環境の保護, 資源の有効利用, ゴミ問題への 取り組みといった様々な側面から, 古紙の再生技術は 今大きな転換期に差しかかっていると言えよう。

古紙再生技術の進歩の方向は言うまでもないことで はあるが，異物の少ないきれいなパルプをいかに少な いエネルギーで再生するかということが第一番目に上 げられる。また最近では製品, 商品の一生涯にわたる 環境負荷を科学的に評価する製品ライフライクル・ア セスメント（LCA）が提唱されており，われわれ機 珹メーカーは既成の考え万にとらわれることなく，そ ういった側面も十分に考慮した上で技術を構築してい く必要があると考える。

*平成 9 年度年次大会講演（講演 No.B 1-21）
当社では長年にわたり培ってきた経験，ノウハウを 生かしながら，古紙再生におけるスクリーニングシス テムの大幅な改善, 再構築を目標として, 新型スクリ ーンの開発を行っている。平成 6 年にリリースした $\mathrm{MF}$ スクリーンを手始めに，昨年は MFC スクリーン をリリースし，現在も新たな技術完成に取り組んでい る。今回は，当社の提案するスクリーニングシステム の改善に関して，実際にMFスクリーン，MFCスク リーンを採用いただいた実プラントでの成果を紹介し， 今後のシステム再構築の参考にしていただきたいと考 えている。

\section{2. スクリーニングシステムの再構築}

\section{1 従来のスクリーニングシステムの問題点} 従来の装置を用いて構築されてきたスクリーンシス テムは, 高い精選効果と高い歩留りを達成するべく, 
複雑な装置構成にせざるをえなかった。特に「テール ライン」と言われる二次スクリーン以降の部分は, 年々再生処理が難しくなっている原料事情, それにも かかわらずますます高まる再生パルプに対する品質要 求の影響をまともに受ける形で，ますます複雑になり， かつエネルギー消費の増大を余儀なくされている。

このことは従来の装置の組み合わせでシステムを構 築している限り, 多少のフローの組みかたの違いはあ 机避けることのできないことである。すなわち, 従来 の装置のもつ特性がこういつた複雑かつエネルギー浪 費型のシステムにせざるを得ない原因となっているの である。

具体的には従来のスクリーン装置はテール量を多く とらなければ（リジェクト率を大きくしなければ）高 い出口品質を保つ事ができないという特性がある。し たがって高い步留りを実現するためには，多次にわた ってスクリーンを設備せざるをえない。

また，歩留り向上のために使われる従来の高速離解 装置は 1 パスで十分な未離解成分の解繊効果を発揮す るために，大きな機械的剪断力を持っている。しかし， 機械的剪断力を大きくするほど異物の細分化を招くた め，スクリーンでの異物の分離が難しくなる。したが ってスクリーン出口の品質低下を防ぐためにはスクリ ーンの目孔サイズを微小なものにする必要が生じ, ス クリーン処理濃度を低くせざるを得ない。このことは スクリーン装置の処理能力の低下を招き, 動力原単位 が悪化することになる。すなわち，このような従来の 装置の致命的欠点ともいえる特性を克服することがス クリーニングシステムの再構築の必須条件となるので ある。

\subsection{MFC，MF スクリーンの完成}

これまでは理想的な古紙回収システムを構築しよう とするほど, 従来の装置の組み合わせでは先に述べた ような理由から非常に複雑かつエネルギー浪費型のシ ステムにせざるを得なかった。しかし逆の見方をすれ ば，精選効果を良好に保ちながらリジェクト率を小さ くでき，異物の細分化を防ぎながら未離解片を解繊す る技術が完成すれば，シンプルなシステム構成で，か つ少ないエネルギーで歩留りの高い異物除去システム の構築が可能となるのである。

当社の $\mathrm{MFC}, \mathrm{MF}$ の両新型スクリーンは装置内部 での原料の循環という原理を用いて他ならぬこの技術 を実現した画期的装置である。平成 6 年に完成りリ一 スしたMFスクリーンの納入実績は既に 100 台を超 えようとしており，平成 8 年に完成リリースした MFC スクリーンも着々と実績を上げつつある。先に
リリースした MF スクリーンは精選ステージ，言い 換えればスリットスクリーンステージ専用の装置であ り，追ってリリースしたMFCスクリーンは粗選ステ ージすなわちホールスクリーンステージ専用の装置で ある。この 2 台の装置は共に装置内部での原料循環と いう原理を生かして, 従来のカスケードフローを1台 の装置に集約したものであり，その内部構造は図 1 に 示すとおりである。詳細な説明は昨年度の年次大会で ご報告したので今回は省略させて頂く。

\subsection{MFC, MFスクリーンを用いたスクリーン システムの再構築}

MFC, MFスクリーンは出口原料の品質を従来型 のスクリーンの精選度と同等以上に保ちながら, 従来 型のスクリーンでは 25 35\%はとる必要があったリ ジェクト率を 5 10\%と大幅に低くすることができる。 このことによって, 従来の複雑なスクリーンシステム は大幅に簡素化され, 省エネルギー型スクリーンシス テムへと再構築することが可能になった。

MFC, MFスクリーンを用いてスクリーンシステ ムを再構築する場合, その成果を最も顕著に実現でき るのは従来のスクリーンシステムの一次粗選スクリー ンを MFCスクリーンに，また一次精選スクリーンを MF スクリーンに変更することである。それぞれの一 次スクリーンのリジェクト量は従来の $4 \sim 6$ 分の 1 と
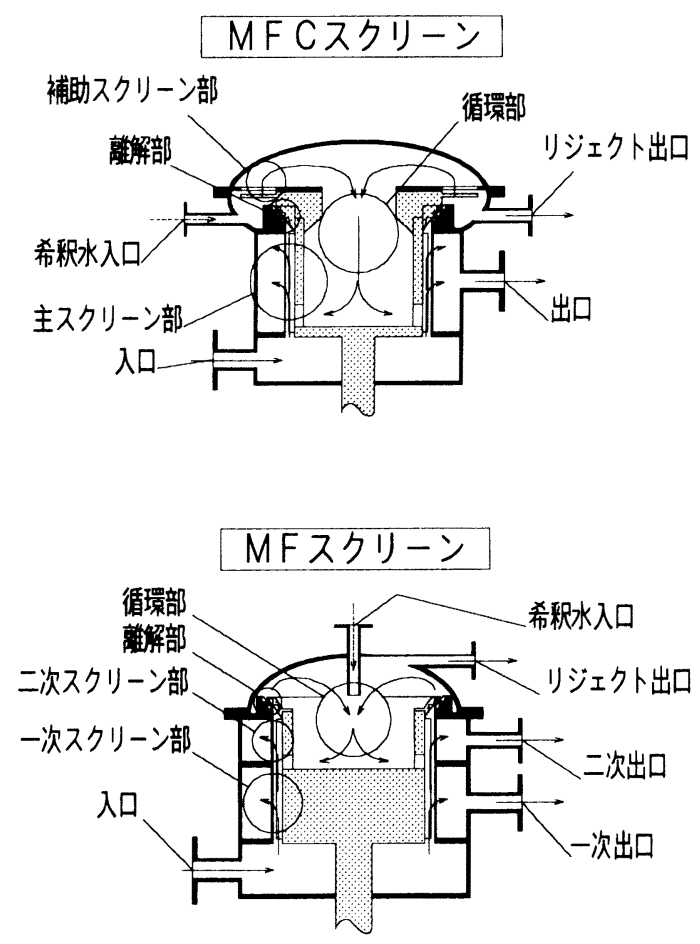

図 1 新型スクリーンの内部構造 


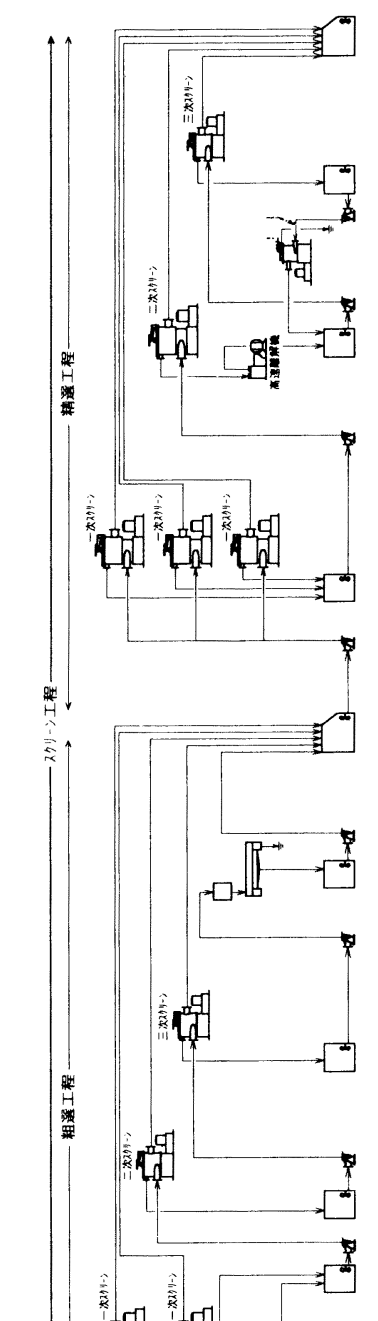

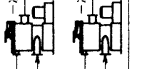
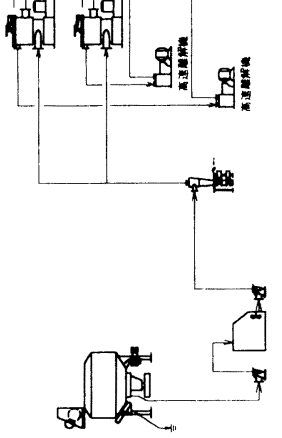

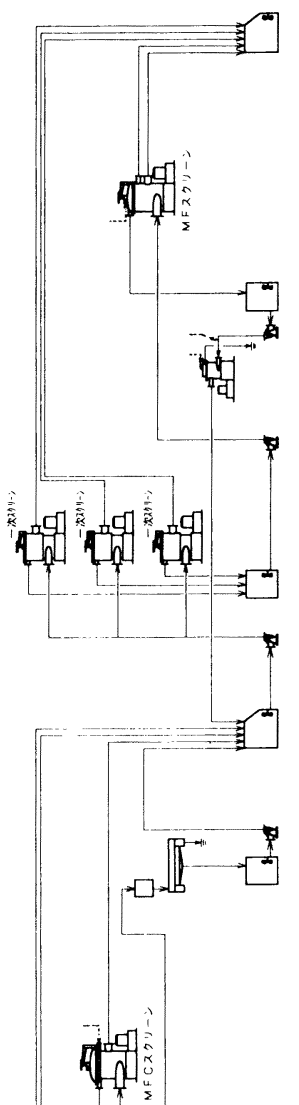

메네
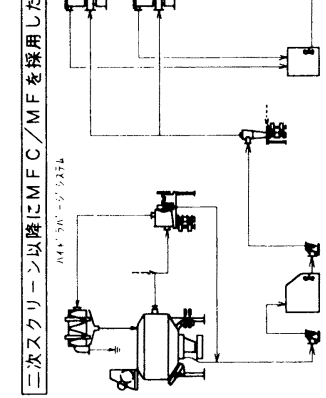
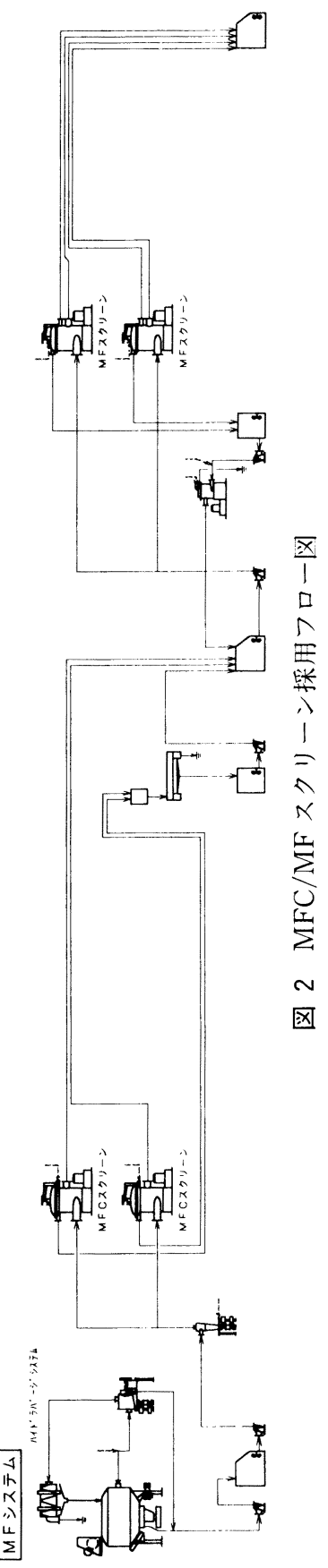
なり，テール系の負担は格段に小さくなり，これを直 接最終テールスクリーンで処理してスクリーンシステ ムを完結させることが可能となる。その場合置き換え られる部分で約 $50 \%$ の省エネルギーが達成される。 処理量が多く一度に大規模な装置変更が難しい場合, 二次スクリーンに MFC, MFスクリーンを採用する ケースも珍しくない。処理量や製品グレードにもよる が粗選, 精選の各ステージで三次あるいは四次スクリ ーンまで設備しているプラントも多く見られる。この ようなシステムでは二次スクリーンとして MFC, MFスクリーンを採用し, 一次スクリーンを除く二次 以降のテールラインを大幅に簡略化し, 成果を上げて いる例も多い（図 2)。省エネルギーばかりに目がい きがちであるが，スクリーンシステムの出口品質の向 上を目的としたシステム再構築でも MFC, MFスク リーンは導入効果の高い装置である。従来型の装置を 用いたスクリーンシステムで出口品質の向上を目的と して改造を行う場合, 粗選, 精選それぞれのステージ のスクリーンシリンダの目穴サイズを小さくするのが 手っ取り早い方法である。ところが従来のスクリーン 装置の場合, 目穴を小さくするとリジェクト率を大き くしてやる必要も生じる。そうすると当然テールライ ンのキャパシティーが足りなくなるという問題が発生 する。

ところが一次スクリーンとして MFC, MF スクリ ーンを導入すれば, 目孔サイズを小さくしてもリジェ クト量が少なくできるためテールラインの負荷が上が るようなことはなく，そのままの設備で十分に対応で きる。あるいは一次スクリーンは従来の装置のままで 目孔を小さくして，二次スクリーンに MFC，MFス クリーンを導入して最終テールスクリーンの負荷を下 げることも可能である。 MFC，MFスクリーンの導 入による効果として, 大幅な省エネルギー, 出口品質 の台上が達成されることはお判り頂けたと思うが，プ
ラントの装置数が少なくなることから省人化も可能と なることも見逃すことは出来ない。事実, 導入後オぺ レータの人員を削減した顧客も少なくない。

精選工程用の MF スクリーンは一次出口と二次出 口が分かれているが，これを有効に利用したシステム も実際に稼働中である。実施例では一次の出口原料を ライナーの表下層用, 裏層用に使用し, 二次の出口原 料をクリーナー処理した上で同じくライナーの中層用 に使用している (図 3)。このように一次と二次の原 料を適材適所で使い分けることによって, 原料システ ム全体を簡略化し省エネルギーを達成することも可能 である。

\section{4 離解工程での異物除去の重要性}

スクリーンシステムの再構築を検討する場合，スク リーン装置を使用する部分のみを考えればよいわけで はない。というのは異物を形状で分離するという原理 を利用する場合, 除去対象異物の大きさというのが非 常に重要な意味を持っているからである。すなわち古 紙に含まれるさまざまな異物を細かく砕いてしまうと， 容易に分離することはできなくなるのである。

古紙に含まれる異物を砕かないということはいうま でもなく大きな難問である。特に回収古紙をスラリー 状に解繊するためのパルパー装置においては, 少ない 動力で多くの原料を処理することが求められており, そのため大きな機械的剪断力をかけていわゆる「離 解」を行っている。

最近ではこの工程において, 当社のハイドラパージ システムのようなパルパーデトラッシングシステムを 付加する例が多く見られるようになったが，このよう なシステムは今後必須のものとなると考える。すなわ ち古紙から異物を除去するというテーマをシステマテ イックに考えた場合, 異物は工程を経るにしたがって 細分化の機会が増えるわけであり, 一番最初の工程で ある「離解工程」で大きな異物を次工程に送り込まれ

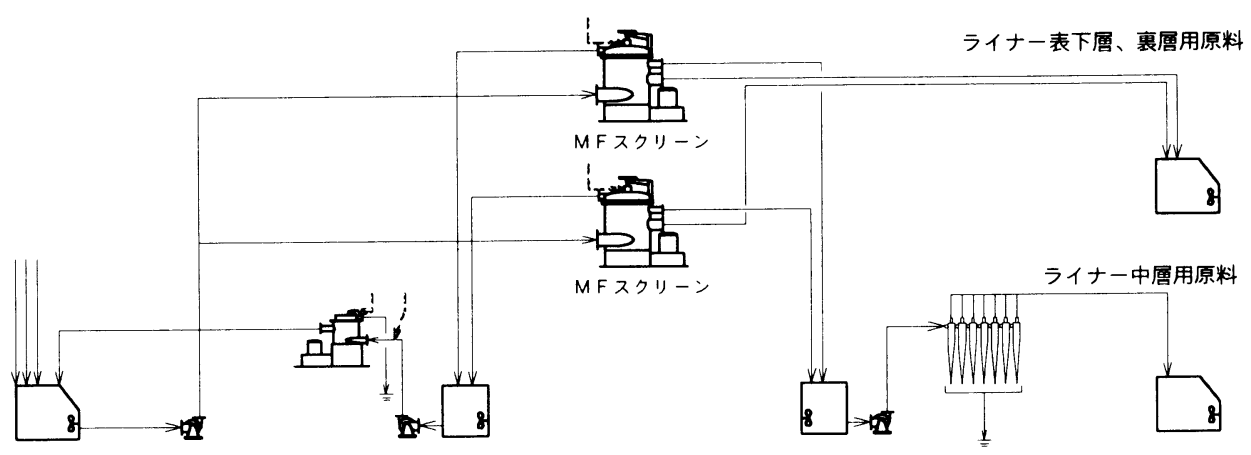

図 $3 \mathrm{MF}$ スクリーンを使ったライナー原料調成システム 
るサイズにまで細かくしてしまわないうちに除去する ことは, スクリーニングの再構築を検討する際必要欠 くべからざる要件であると言つても過言ではない。ま た，異物を細分化しやすい従来の 4 6\%という低濃 度離解から, 中濃度 $(7 \sim 9 \%)$, 高濃度 (12 15\%) という濃度領域での離解も十分に検討の価值がある。

\section{MFC, MF スクリーンの導入例}

\section{1 段古紙, 雑古紙併用粗選ラインー次 MFC} スクリーン

この例では, 約 $400 \mathrm{~T} / \mathrm{D}$ の雑古紙, 段古紙併用ラ インで長年他社の $190 \mathrm{~kW} の$ 粗選専用装置を 4 台使用 してきたが，この 4 台を 36-MFCスクリーン（315 kW）1台に置き換えることを実施した。

リジェクト率は雑古紙処理で 3 6\%, 段古紙処理 で4〜7\%であり, 約 $50 \%$ という大幅な省エネルギー を達成するにいたったばかりか, 完成原料の品質向上 も実現することができた（表 1, 図 4)。

表 1 一次 MFC スクリーン導入効果 (例 1)

\begin{tabular}{|c|c|c|}
\hline \multirow{3}{*}{$\begin{array}{c}\text { 従来システム } \\
\text { 動力 } \\
(\mathrm{kW})\end{array}$} & 主要機器 & 760 \\
\hline & 周辺機器 & 0 \\
\hline & 合計 & 760 \\
\hline MFC 動力 & $(\mathrm{kW})$ & 315 \\
\hline 省工ネ率 & $(\%)$ & 58.5 \\
\hline \multirow{2}{*}{$\begin{array}{c}\text { リジェクト率 } \\
(\%)\end{array}$} & 雑古紙 & $3 \sim 6$ \\
\hline & 段古紙 & $4 \sim 7$ \\
\hline \multicolumn{2}{|c|}{ その他実施効果 } & 品質向上 \\
\hline
\end{tabular}

表 2 二次 MFC スクリーン導入効果 (例 2)

\begin{tabular}{|c|c|c|}
\hline \multirow{3}{*}{$\begin{array}{c}\text { 従来システム } \\
\text { 動力 } \\
(\mathrm{kW})\end{array}$} & 主要機器 & 290 \\
\hline & 周辺機器 & 37 \\
\hline & 合計 & 327 \\
\hline $\mathrm{MFC}$ 動力 & $(\mathrm{kW})$ & 150 \\
\hline 省工ネ率 & $(\%)$ & 54.1 \\
\hline \multirow{2}{*}{$\begin{array}{c}\text { リジェクト率 } \\
(\%)\end{array}$} & 雑古紙 & $5 \sim 7$ \\
\hline & 段古紙 & $8 \sim 11$ \\
\hline \multicolumn{2}{|l|}{ その他実施効果 } & 粕減少 \\
\hline
\end{tabular}

3.2 段古紙, 雑古紙併用粗選ラインニ次 MFC スクリーン

この例では, 約 $500 \mathrm{~T} / \mathrm{D}$ の雑古紙, 段古紙併用ラ インで $110 \mathrm{~kW}$ の二次 $30 \mathrm{PH}$-スクリーン, $30 \mathrm{~kW} の$ 三次 $12 \mathrm{PH}$-スクリーン, $150 \mathrm{~kW}$ の No.19 ハイドラ フレーカを使用してきたが, この二次以降の部分を $150 \mathrm{~kW}$ の 24-MFC スクリーン 1 台に置き換えるこ とを実施した。

スクリーン間をつなぐタンクのアジテータ，ポンプ を含約 50\%の省エネルギーを達成するにいたった ばかりか, 粗選, 精選両工程の排出粕の量を減少する ことができた（表 2, 図5)。

\section{3 段古紙粗選ライン一次 MFC スクリーン}

この例では, 約 $350 \mathrm{~T} / \mathrm{D}$ の段古紙処理ラインで $110 \mathrm{~kW}$ の一次 $30 \mathrm{PH}$-スクリーン, $75 \mathrm{~kW}$ の二次 24 $\mathrm{PH}$-スクリーン, $37 \mathrm{~kW}$ の三次 8-PH スクリーンお よび $75 \mathrm{~kW}$ のハイドラフレーカを使用してきたが, これを $250 \mathrm{~kW}$ の 30-MFC スクリーン 1 台に置き換 えることを実施した。

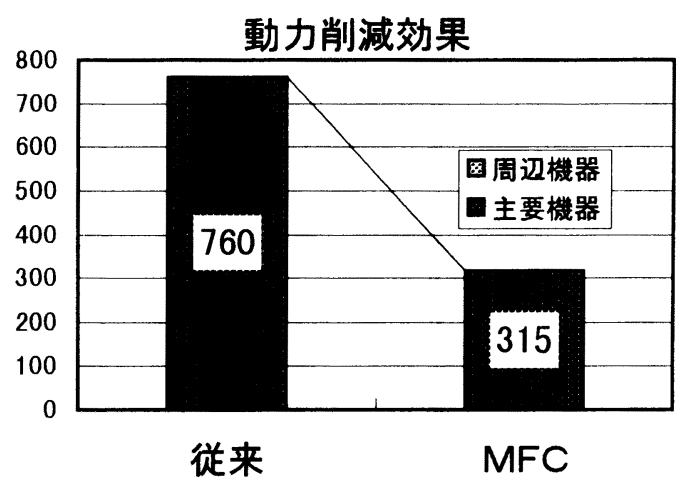

図 $4 \mathrm{MF}$ スクリーン導入による省エネ効果（例 1)

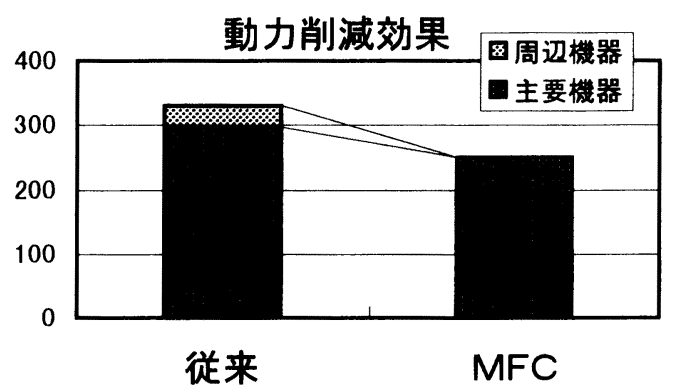

图 5 二次 MF スクリーン導入省エネ効果（例 2) 
スクリーン間をつなぐタンクのアジテータ，ポンプ を含め約 $25 \%$ の省エネルギーを達成した（表 3, 図 6)。

3.4 段古紙精選ライン 1 次 30-MF スクリーン

この例では, 約 $100 \mathrm{~T} / \mathrm{D}$ の段古紙処理ラインで 95 $\mathrm{kW}$ の一次 $24 \mathrm{PS}-$ スクリーン, $37 \mathrm{~kW}$ の二次 12 PSスクリーンを使用してきたが，これを $95 \mathrm{~kW} の 30-$ MF スクリーン 1 台に置き換えることを実施した。

スクリーン間をつなぐタンクのアジテータ，ポンプ を含め約 $40 \%$ の省エネルギーを達成した (表 4, 図 7)。

また，このシステムでは MFスクリーンの一次出 口はライナ一の表下層および裏層用原料に使用し，二 次出口はクリーナー処理した上でライナーの中層用原 料として使用しており, 原料調成設備のコンパクト化 にも一役買っている。

\section{5 雑古紙精選ライン 1 次 36-MF スクリーン}

この例では, 約 $200 \mathrm{~T} / \mathrm{D}$ の段古紙処理ラインで $150 \mathrm{~kW}$ の 1 次 $36 \mathrm{PS}$-スクリーン, $130 \mathrm{~kW}$ の二次 30 PS-スクリーン, $37 \mathrm{~kW}$ の三次 $12 \mathrm{X}-\mathrm{PS}$ スリーン および $75 \mathrm{~kW}$ のハイドラフレーカを使用してきたが, これを $150 \mathrm{~kW} の 30-\mathrm{MF}$ スクリーン 1 台に置き換え ることを実施した。

表 3 一次 MFC スクリーン導入効果 (例 3)

\begin{tabular}{|c|c|c|}
\hline \multirow{3}{*}{$\begin{array}{c}\text { 従来システム } \\
\text { 動力 } \\
(\mathrm{kW})\end{array}$} & 主要機器 & 297 \\
\hline & 周辺機器 & 33 \\
\hline & 合計 & 330 \\
\hline MFC 動力 & $(\mathrm{kW})$ & 250 \\
\hline 省工ネ率 & (\%) & 24.2 \\
\hline リジェクト率 & (\%) & $3 \sim 8$ \\
\hline その他実施効 & & 品質向上 \\
\hline
\end{tabular}

表 4 一次 MF スクリーン導入効果 (例 4)

\begin{tabular}{|c|c|c|}
\hline \multirow{3}{*}{$\begin{array}{c}\text { 従来システム } \\
\text { 動力 } \\
(\mathrm{kW})\end{array}$} & 主要機器 & 132 \\
\hline & 周辺機器 & 30 \\
\hline & 合計 & 162 \\
\hline MFC 動力 & $(\mathrm{kW})$ & 95 \\
\hline 省工ネ率 & $(\%)$ & 41.4 \\
\hline リジェクト率 & $(\%)$ & $5 \sim 7$ \\
\hline その他実施効 & & 品質向上 \\
\hline
\end{tabular}

スクリーン間をつなぐタンクのアジテータ，ポンプ を含め実に約 $70 \%$ も省エネルギーを達成するにい たった（表 5, 図 8)。

\section{6 模造古紙精選ラインー次 24-MF スクリーン}

この例では, 約 $70 \mathrm{~T} / \mathrm{D}$ の段古紙処理ラインで 75 $\mathrm{kW}$ の一次 $24 \mathrm{PS}-$ スクリーン, $30 \mathrm{~kW}$ の二次 12 PSスクリーンを使用してきたが，これを $75 \mathrm{~kW}$ の 24MF スクリーン 1 台に置き換えることを実施した。

スクリーン間をつなぐタンクのアジテータ，ポンプ を含め約 $40 \%$ の省エネルギーを達成した(表 6, 図9)。

\section{4.おわりに}

今回は前年度ご紹介した当社の新機種 MF スクリ ーン，MFCスクリーンの特長を生かしたスクリーン システムの再構築およびその実施例を報告させていた だいた。

本装置に対するユーザーの方々のご理解とご応援が あってこそ今回のご報告が可能になったことは言うま でもないことであり，この場をお借りしてお礼を申し 上げる。

また昨年度は紙パルプ技術協会の「佐々木賞」に続

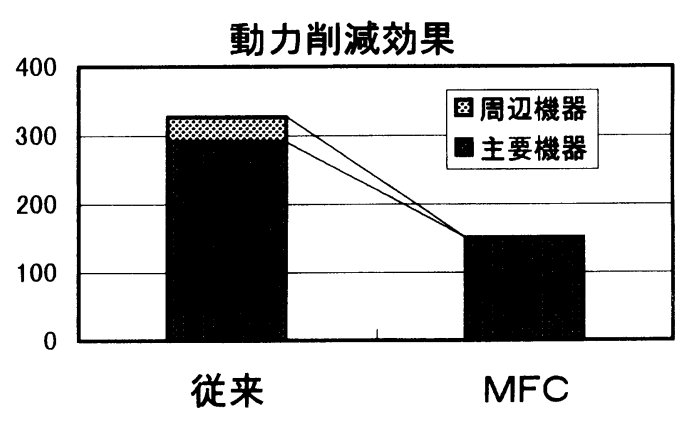

図 6 一次 MFスクリーン導入省エネ効果（例 3)

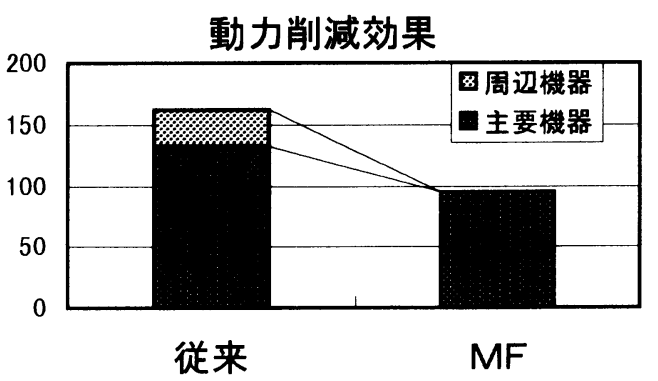

図 7 一次 MF スクリーン導入省エネ効果（例 4) 
表 5 一次 $\mathrm{MF}$ スクリーン導入効果 (例 5)

\begin{tabular}{l|c|c}
\hline \multirow{2}{*}{$\begin{array}{c}\text { 従来システム } \\
\text { 動力 } \\
(\mathrm{kW})\end{array}$} & 主要機器 & 392 \\
\cline { 2 - 3 } & 周辺機器 & 111 \\
\cline { 2 - 3 } & 合計 & 503 \\
\hline $\mathrm{MF}$ 動力 & $(\mathrm{kW})$ & 150 \\
\hline 省エネ率 & $(\%)$ & 70.2 \\
\hline リジェクト率 & $(\%)$ & $3 \sim 6$ \\
\hline \multicolumn{2}{c|}{ その他実施効果 } & 品質向上 \\
\hline
\end{tabular}

表 6 一次 MF スクリーン導入効果 (例 6)

\begin{tabular}{l|c|c}
\hline \multirow{2}{*}{$\begin{array}{c}\text { 従来システム } \\
\text { 動力 } \\
(\mathrm{kW})\end{array}$} & 主要機器 & 105 \\
\cline { 2 - 3 } & 周辺機器 & 18.5 \\
\cline { 2 - 3 } & 合計 & 123.5 \\
\hline $\mathrm{MF}$ 動力 & $(\mathrm{kW})$ & 75 \\
\hline 省エネ率 & $(\%)$ & 39.3 \\
\hline リジェクト率 & $(\%)$ & $4 \sim 6$ \\
\hline その他実施効果 & 品質向上 \\
\hline
\end{tabular}

いて, 同協会の推茂により優秀省エネルギー機器表彰 において「通産大臣賞」をいただくに至った。これは 本装置の性能面だけが評価されたのではなく，「リサ イクル」というテーマに長年携わってきた紙パルプ業 界に対する評価と言っても過言ではないような気がす る。
動力削減効果

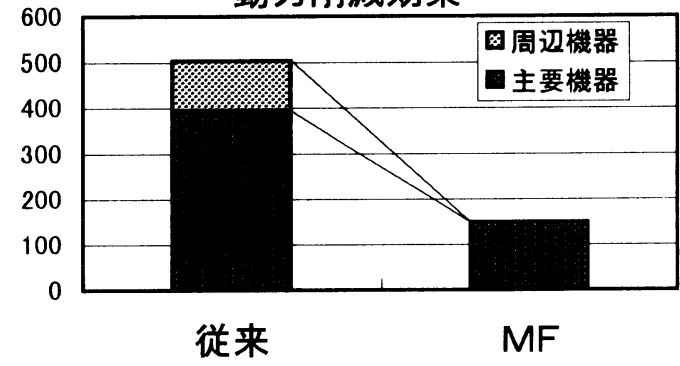

図 8 一次 MF スクリーン導入省エネ効果（例 5)

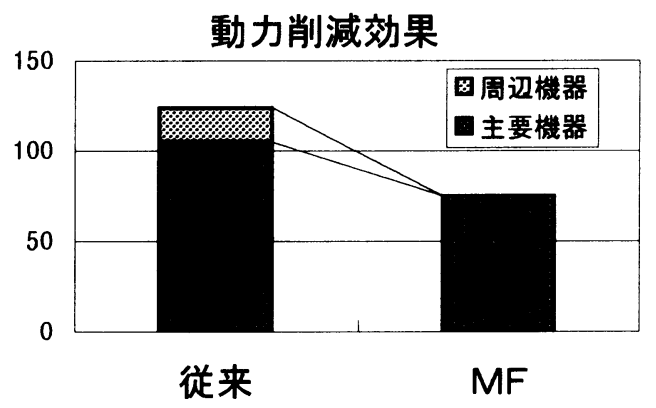

図 9 一次 MF スクリーン導入省エネ効果（例 6)

今後ますます多方面にわたる資源の保護，リサイク ルの重要性が取り上げられるようになることは明らか である。当社は紙パルプ業界がこのテーマに関する優 等生でい続けられるために，少しでもお役に立てるよ うに努力を続ける所存である。 